\title{
Purification and identification of the Kazal domain of a novel serine protease inhibitor, Hespintor, through a bacterial (Escherichia coli) expression system
}

\author{
YONG-ZHI LUN, XUE-LEI WANG and JIE FENG \\ Liaoning Provincial University Key Laboratory of Biophysics, \\ College of Medicine, Dalian University, Dalian, Liaoning 116622, P.R. China
}

Received January 21, 2014; Accepted April 24, 2014

DOI: $10.3892 /$ ijmm.2014.1778

\begin{abstract}
In this study, Hespintor, a protein with unknown function, was screened and obtained from the hepatoblastoma cell line, HepG2, using suppression subtractive hybridization (SSH). Sequence analysis demonstrated that the protein is a novel secreting member of the Kazal-type serine protease inhibitor (serpin) family, and possesses the basic structure of serpin, which is highly homologous to esophageal cancer-related gene 2 (ECRG2). To further elucidate its biological functions, the Hespintor protein was expressed and purified. The coding sequence of the Hespintor Kazal domain was cloned into the prokaryotic expression vector, pET-40b(+), and was then transformed into host bacteria (Escherichia coli) Rosetta (DE3). The optimally expressed recombinant fusion protein,Hespintor-Kazal, with a molecular weight of $42 \mathrm{kDa}$ was obtained by $0.25 \mathrm{mmol} / \mathrm{l}$ isopropyl $\beta$-D-1-thiogalactopyranoside (IPTG) induction at $30^{\circ} \mathrm{C}$ for $5 \mathrm{~h}$. Western blot analysis was performed to further confirm the specificity of the recombinant protein, Hespintor-Kazal. The recombinant fusion protein, Hespintor-Kazal, was expressed in the host bacteria in the form of an inclusion body. Two-step metal chelating affinity chromatography and anion exchange chromatography columns were used to purify the recombinant protein. The preliminary activity identification results revealed that the purified recombinant fusion protein, Hespintor-Kazal, specifically inhibited the hydrolysis activity of trypsin, suggesting that Hespintor has potential value as a novel antitumor drug.
\end{abstract}

\section{Introduction}

The most crucial step in the progression of cancer is the invasion and metastasis of tumor cells, which depends on certain tumor cell secretions that can hydrolyze the extracellular matrix (ECM)

\footnotetext{
Correspondence to: Dr Yong-Zhi Lun, Liaoning Provincial University Key Laboratory of Biophysics, College of Medicine, Dalian University, Dalian, Liaoning 116622, P.R. China

E-mail: lunyz@163.com
}

Key words: serine protease inhibitor, Hespintor, Kazal domain, prokaryotic expression and basement membrane (BM). Tumor cells first secrete urokinase-type plasminogen activator (uPA), which is a serine protease that can activate plasminogen and produce plasmin (PLM). PLM then degrades the ECM, and can also activate the precursor and produce matrix metalloproteinases, which are involved in the hydrolysis of ECM. Finally, the ECM and BM are hydrolyzed and the tumor cells spread (1). Therefore, controlling the levels or functions of UPA can be used for cancer treatment. In particular, the inhibition of uPA activity by Kazal-type serine protease inhibitors is the most direct approach and has the most prospects in clinical application (2-4).

Suppression subtractive hybridization ( $\mathrm{SSH}$ ) was used in the present study to investigate the transregulation of the target genes by HBV RT/DNA polymerase, and a protein of unknown function was screened and obtained from the hepatoblastoma cell line, HepG2. The gene was a new member of the Kazal-type serpin family identified by RT-PCR verification and bioinformatics, and was named Hespintor (GenBank Accession no. DQ438947).

The cloned Hespintor Kazal domain encoding region from the HepG2 cells was subcloned into the prokaryotic expression vector, pET-40b(+), in the present study. Large quantities of Hespintor-Kazal recombinant protein with fusion tag proteins were expressed, as shown by isopropyl $\beta$-D-1thiogalactopyranoside (IPTG) induction. High-efficiency expression of the recombinant fusion protein, Hespintor-Kazal, was obtained by optimization screening under IPTG induction conditions. Finally, the purified recombinant protein with specific inhibition of trypsin hydrolysis activity was obtained by a further two-step purification of the $\mathrm{Ni}^{2+}$ and $\mathrm{Q}$ columns and renaturation on columns, which provides the basis for the research into the next step.

\section{Materials and methods}

Plasmids and strains. The cloning vector, pMD 20-T/Hespintor cDNA, and Escherichia coli DH5 $\alpha$ were obtained from our laboratory; Escherichia coli Rosetta (DE3) and the prokaryotic expression vector, pET-40b(+), were purchased from the Physical and Chemical Analysis and Testing Center of Beijing; the pMD 19-T Simple Vector was purchased from Takara Biotechnology Co., Ltd. (Dalian, China). 
Primers. The sequence-specific primers with restriction endonuclease (BamHI and HindIII) cleavage sites of forward (5'-GGA TCCGCCTAAGCCCCG-3') and reverse (5'-GCGCAAGC TTATCACATTTTCCATATTTTTC-3') were designed according to the gene sequence of Hespintor (GenBank Accession no. DQ438947) and were synthesized by Takara Biotechnology Co., Ltd.).

Main reagents. Restriction Enzyme Starter BOX, Permix Ex Taq Version 2.0, $\lambda$-HindIII digest and DL2 000 DNA Marker were purchased from Takara Biotechnology Co., Ltd.; PageRuler Prestained Protein Ladder was purchased from Fermentas (Waltham, MA, USA); mouse anti-human His Tag monoclonal antibody (primary antibody) was purchased from Kebaiao Biotech Co., Ltd. (Beijing, China); goat anti-mouse HRP-IgG (secondary antibody) was purchased from Beijing Sequoia Jinqiao Biological Technology. Co., Ltd. (Beijing, China); bovine serum albumin (BSA) and trypsin (active $\geq 250 \mathrm{NF} \mathrm{U} / \mathrm{mg}$ ) were purchased from Amresco Inc. (Solon, $\mathrm{OH}$, USA); Na-benzoyl arginine-DL-p-nitrophenyl amide hydrochloride (BAPNA) was purchased from Sigma (St. Louis, MO, USA); $\mathrm{Ni}^{2+}$ column $\left(\mathrm{Ni}^{2+}\right.$-Histrap FF crude $\left.5 \mathrm{ml}\right)$ and Q column (Histrap Q FF column $1 \mathrm{ml}$ ) were purchased from GE Healthcare (Piscataway, NJ, USA); Coomassie brilliant blue G250 was purchased from Solarbio (Beijing, China).

Construction and identification of prokaryotic expression vector, PET-40b(+)/Hespintor-Kazal. The domain coding sequence of the Kazal-type Hespintor was amplified by PCR, with pMD 20-T/Hespintor cDNA as the template. The PCR products were analyzed by $3 \%$ agarose gel electrophoresis and were purified and refolded. The purified target gene fragment was incubated with the pMD 19-T Simple Vector at room temperature overnight for ligation, and the ligation product was then transformed into DH5 $\alpha$ competent cells. The plasmids were extracted using alkaline lysis and further sequenced to prove that the target gene fragment was inserted into the $\mathrm{T}$ vector correctly. The target gene fragment was then digested from the recombinant $\mathrm{T}$ vector with BamHI/HindIII, and was purified and obtained by $3 \%$ agarose gel electrophoresis. The purified target fragment was ligated to the prokaryotic expression vector pET-40b(+) digested with the same restriction enzymes, and the ligation product was used to transform Escherichia coli Rosetta (DE3). The plasmids were extracted by alkaline lysis for further enzyme digestion and protein identification.

Induction of expression and optimal induction conditions of recombinant fusion protein, Hespintor-Kazal. pET-40b(+)/Hespintor was transformed into the Escherichia coli Rosetta (DE3) strain and cultured in LB liquid medium containing $34 \mu \mathrm{g} / \mathrm{ml}$ chloramphenicol and $10 \mu \mathrm{g} / \mathrm{ml}$ kanamycin overnight at $37^{\circ} \mathrm{C}$. The strains were scaled up for cultivation according to proportions. Optimization was conducted by selecting different induction conditions. The effects of induction time, the final IPTG concentration and the induction temperature on the expression of the target proteins were investigated. Three parallel groups were tested under each condition. The strains were harvested by centrifugation, and 15\% SDS-PAGE was used to analyze the optimal induction conditions.
Purification and identification of the recombinant fusion protein, Hespintor-Kazal. Western blot analysis was used to determine the expression of the recombinant proteins. The harvested bacteria induced by the optimal conditions were lysed by ultrasonic wave. The precipitate (i.e., inclusion) was dissolved in $8 \mathrm{~mol} / \mathrm{l}$ urea solution, and the supernatants were harvested after centrifugation. Solution A ( $8 \mathrm{~mol} / \mathrm{l}$ urea, $0.5 \mathrm{~mol} / 1 \mathrm{NaCl}, 20 \mathrm{mmol} / \mathrm{l}$ imidazole; $\mathrm{pH} 8$ ) was used to balance the $\mathrm{Ni}^{2+}$ column, and the supernatant was applied to the column after sucking filtration and degassing. Solution A was used to flush continuously, and solution $\mathrm{B}(0.5 \mathrm{~mol} / \mathrm{l} \mathrm{NaCl}$, $20 \mathrm{mmol} / \mathrm{l}$ imidazole; $\mathrm{pH} 8$ ) was used in protein refolding with the gradient elution program from $0 \% \mathrm{~B}$ to $100 \% \mathrm{~B}$. The refolding time of the protein was $150 \mathrm{~min}$. During the process, the fusion protein solution was adjusted from $8 \mathrm{~mol} / \mathrm{l}$ urea to $0 \mathrm{~mol} / \mathrm{l}$ urea. The denatured fusion proteins were folded again and formed a spatial structure with biological activity (column refolding). All processes were conducted in low temperature environments. Following complete urea removal, solution $\mathrm{C}$ $(0.5 \mathrm{~mol} / \mathrm{l} \mathrm{NaCl}, 500 \mathrm{mmol} / \mathrm{l}$ imidazole; $\mathrm{pH}$ 8) was used for elution. The eluting peak was determined by $15 \%$ SDS-PAGE. Solution D (20 mmol/l Tris- $\mathrm{HCl} ; \mathrm{pH} 8)$ was used to balance the $\mathrm{Q}$ column. The samples purified with the $\mathrm{Ni}^{2+}$ columns were diluted with solution D and analyzed. Solution E $(20 \mathrm{mmol} / \mathrm{l}$ Tris- $\mathrm{HCl}, 1 \mathrm{~mol} / \mathrm{l} \mathrm{NaCl}$; $\mathrm{pH}$ 8) was used for gradient elutions. The eluting peaks were determined by $15 \%$ SDS-PAGE. The concentration of the recombinant protein was detected by the Bradford method.

Activity identification of the recombinant fusion protein, Hespintor-Kazal. The activity of the recombinant fusion protein, Hespintor-Kazal, was identified according to the Sigma method with minor modifications. Briefly, 8 tubes with a volume of $5 \mathrm{ml}$ were taken and numbered. Subsequently, $200 \mu 140 \mu \mathrm{g} / \mathrm{ml}$ trypsin followed by $0,20,40,80,120,160$, or $200 \mu \mathrm{l}$ of the recombinant protein purification liquid were added to 7 tubes. To the remaining centrifugation tube, $20 \mu \mathrm{l}$ $1 \mathrm{mmol} / \mathrm{l}$ added, with $\mathrm{HCl}$ as the blank control. Tris- $\mathrm{HCl}$ was used to supplement to a final volume of $2 \mathrm{ml}$, and the reaction was conducted in a $37^{\circ} \mathrm{C}$ water bath for $10 \mathrm{~min}$. To each tube was added $1 \mathrm{mmol} / \mathrm{l} \mathrm{BAPNA}$, and the mixture was incubated in a $37^{\circ} \mathrm{C}$ water bath for $5 \mathrm{~min}$. Finally, $1 \mathrm{ml} 60 \%$ acetic acid was added to each tube to terminate the reaction. The OD value was measured at $595 \mathrm{~nm}$. The inhibition rate of the recombinant fusion protein, Hespintor-Kazal, was calculated according to the following equation and the inhibition curve was obtained:

Inhibition $(\%)=\frac{\left(\Delta \mathrm{A}_{405 \mathrm{~nm} / \mathrm{min}} \text { Uninhibited }-\Delta \mathrm{A}_{405 \mathrm{~nm} / \mathrm{min}} \text { Inhibition }\right)}{\left(\Delta \mathrm{A}_{405 \mathrm{~nm} / \mathrm{min}} \text { Uninhibited }-\Delta \mathrm{A}_{405 \mathrm{~nm} / \mathrm{min}} \text { Blank }\right)} \times 100$

\section{Results}

Construction of the prokaryotic expression vector, HespintorKazal. The Hespintor cDNA consisted of 285 nucleotides, encoding 94 amino acids (Fig. 1). The Phyre ${ }^{2}$ Protein Fold Recognition Server (http://www.sbg.bio.ic.ac.uk/ phyre2) was used to predict and obtain the tertiary structure of Hespintor (Fig. 2). The results revealed that Hespintor consisted of 3 domains: a signal peptide with 1-23 terminal amino acid resi- 


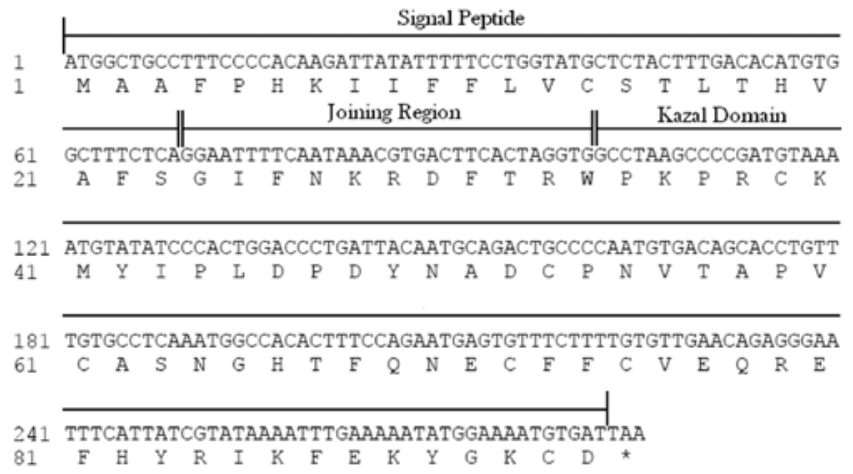

Figure 1. Nucleotide and amino acid sequences of Hespintor.

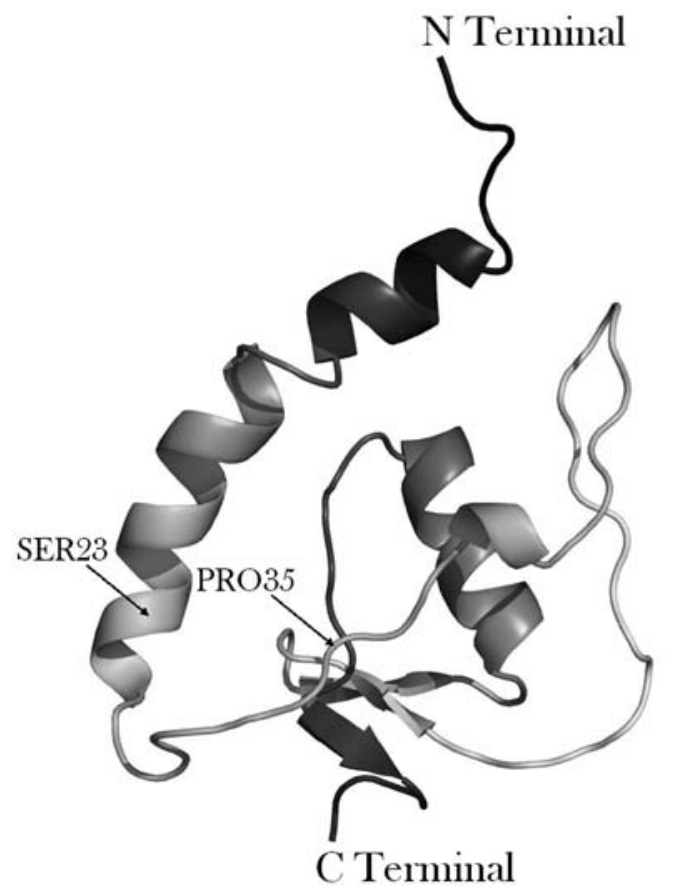

Figure 2. Predicted crystal structure of Hespintor.

dues in the $\mathrm{N}$ terminal, a typical Kazal domain with 35-94 amino acids and a connected region between the $\mathrm{N}$ terminal signal peptide, and a Kazal domain with 24-34 amino acid residues.

The domain coding sequence of the Kazal-type Hespintor was amplified using PCR with pMD 20-T/Hespintor cDNA as the template. The PCR products were detected by $3 \%$ agarose gel electrophoresis. An amplified product of approximately $197 \mathrm{bp}$ was obtained. Following the ligation of the purified PCR product with $\mathrm{T}$ vector, the positive recombinant $\mathrm{pMD}$ 19-T Simple/Hespintor-Kazal was obtained and identified by blue-white screening and double enzyme digestion. The sequencing results demonstrated that the target gene fragments had been correctly inserted into the $\mathrm{T}$ vector. The target gene fragment obtained from the $\mathrm{T}$ vector digested with double enzyme digestions of BamHI/HindIII was ligated to the pET-40b(+) digested with the same enzymes. The enzyme digestion results illustrated that the recombinant prokaryotic

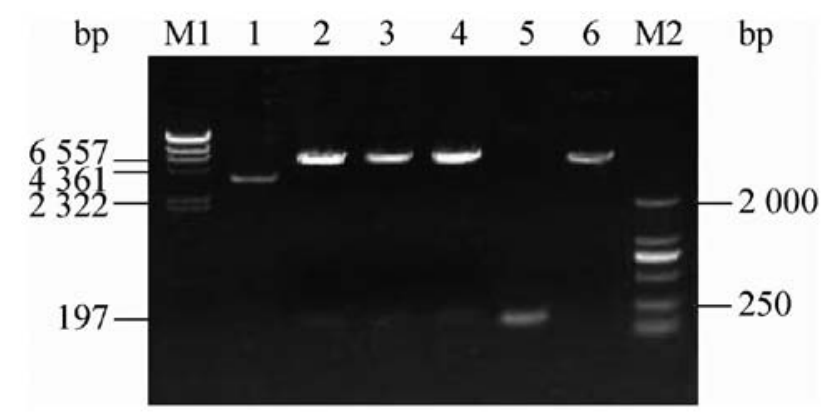

Figure 3. Identification of pET-40b(+)/Hespinto-Kazal by enzyme digestion. Lane M1, $\lambda$-HindIII digest; lane 1: pET-40b(+)/Hespintor-Kazal; lanes 2-4, digestion identification of pET-40b(+)/Hespintor-Kazal with BamHI/ HindIII; lane 5, PCR products of Hespintor-Kazal; lane 6, digestion identification of pET-40b(+) with BamHI/HindIII; lane M2: DL2 000 DNA marker.

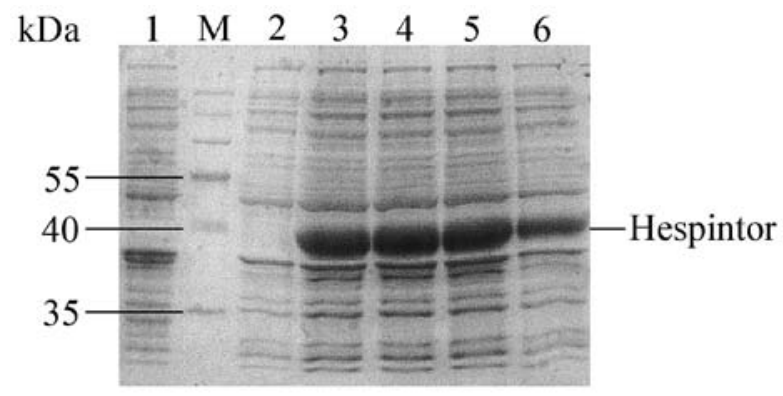

Figure 4. Effect of induction temperature on the expression of Hespintor recombinant protein. Lane 1, Rosetta(DE3)/pET-40b(+) induction; lane M: PageRular pre-stained protein ladder; lane 2, no induction with Rosetta(DE3)/pET-40b(+)/ Hespintor-Kazal; lanes 3-6: Rosetta (DE3)/pET-40b(+)/Hespintor-Kazal induction at different temperatures $\left(24,27,30\right.$ and $33^{\circ} \mathrm{C}$, respectively). The molecular weight of Hespintor recombinant protein was approximately $42 \mathrm{kDa}$ in the SDS-PAGE gel.

expression vector, $\mathrm{pET}-40 \mathrm{~b}(+) /$ Hespintor-Kazal, was successfully constructed (Fig. 3).

Expression conditions and screening of the recombinant fusion protein, Hespintor-Kazal. The recombinant vector, PET-40b(+)/Hespintor-Kazal, was transformed into Escherichia coli Rosetta (DE3). Following the induction of Hespintor expression, 15\% SDS-PAGE was used to analyze the protein levels. The results revealed a distinct protein band with a molecular weight of approximately $42 \mathrm{kDa}$. The screening results of the expression conditions revealed that the induction time had no obvious effect on the expression levels of the recombinant fusion protein, Hespintor-Kazal. However, the expression level of Hespintor-Kazal was relatively high after $5 \mathrm{~h}$ of induction. Furthermore, the concentration of IPTG had no significant effect on the recombinant protein expression. Due to the toxic effects of high concentrations of IPTG on bacteria, $0.25 \mathrm{mmol} / \mathrm{l}$ was selected as the concentration of IPTG. As regards the induction temperature, the expression level of the recombinant protein was only $33^{\circ} \mathrm{C}$. Taking into account the effects of temperature on the growth of bacteria, $30^{\circ} \mathrm{C}$ was selected as the induction temperature (Fig. 4). The obtained supernatant and precipitate following centrifugation of the induction products were analyzed by $15 \%$ SDS-PAGE. 


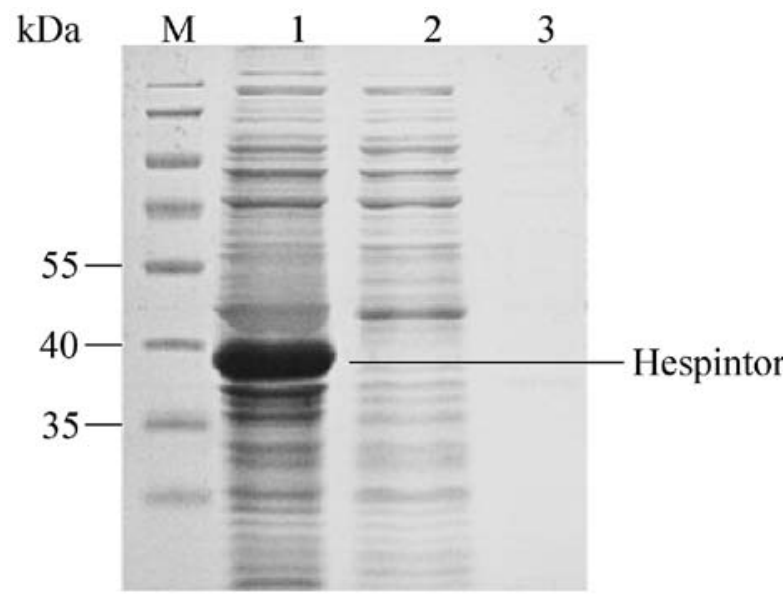

Figure 5. Solubility analysis of crude extracts from induced Rosetta (DE3). Lane M, PageRuler pre-stained protein ladder; lane 1, inclusion body of Rosetta(DE3)/pET-40b(+)/Hespintor-Kazal; lane 2, periplasm parts of Rosetta(DE3)/pET-40b(+)/Hespintor-Kazal; lane 3, supernatant of Rosetta(DE3)/pET-40b(+)/Hespintor-Kazal.

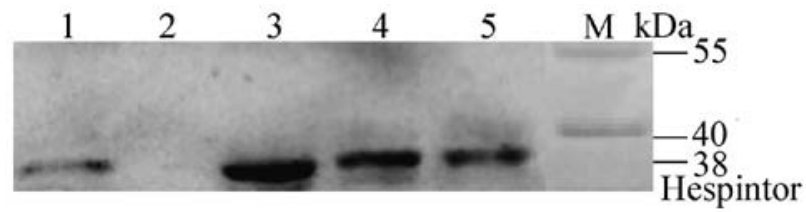

Figure 6. Identification of purified Hespintor recombinant protein by Western blot analysis. Lane M, PageRuler pre-stained protein ladder; lane 1, no induction with Rosetta(DE3)/pET-40b(+)/Hespintor-Kazal; lane 2, Rosetta(DE3)/ pET-40b(+) induction; lanes 3-5, Rosetta(DE3)/pET-40b(+)/Hespintor-Kazal induction with different IPTG comcentrations $(0.25,0.50$ and $0.75 \mathrm{mmol} / 1$, respectively). Recombinant $42 \mathrm{kDa}$ protein was immunodetected using antibodies against His Tag.

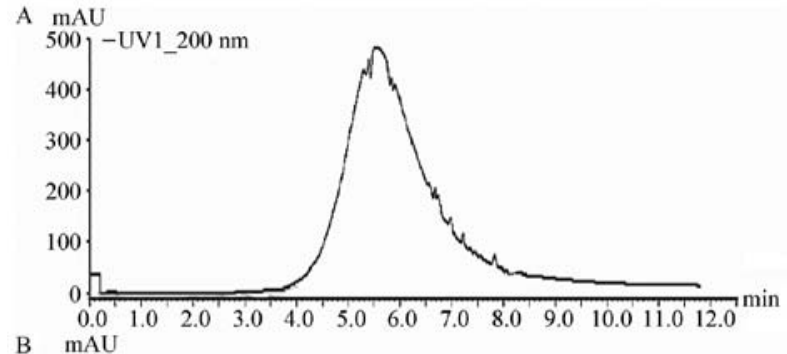

B

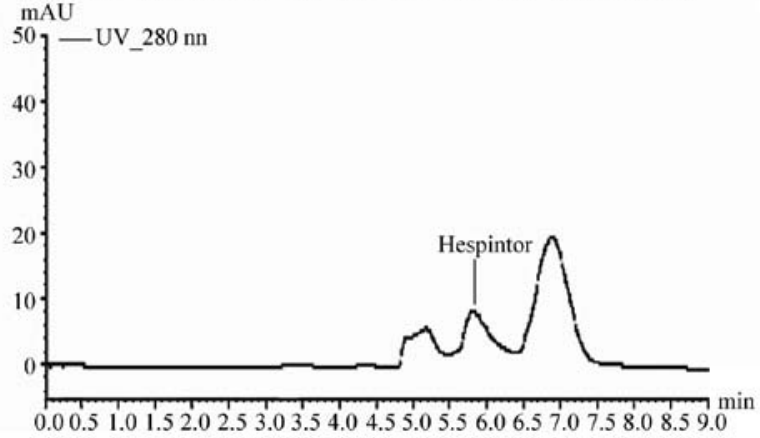

Figure 7. Elution curve of Hespintor recombinant protein from the (A) $\mathrm{Ni}^{2+}$ column and (B) Q column.

The results indicated that the recombinant fusion protein, Hespintor-Kazal, existed in the precipitation in the form of

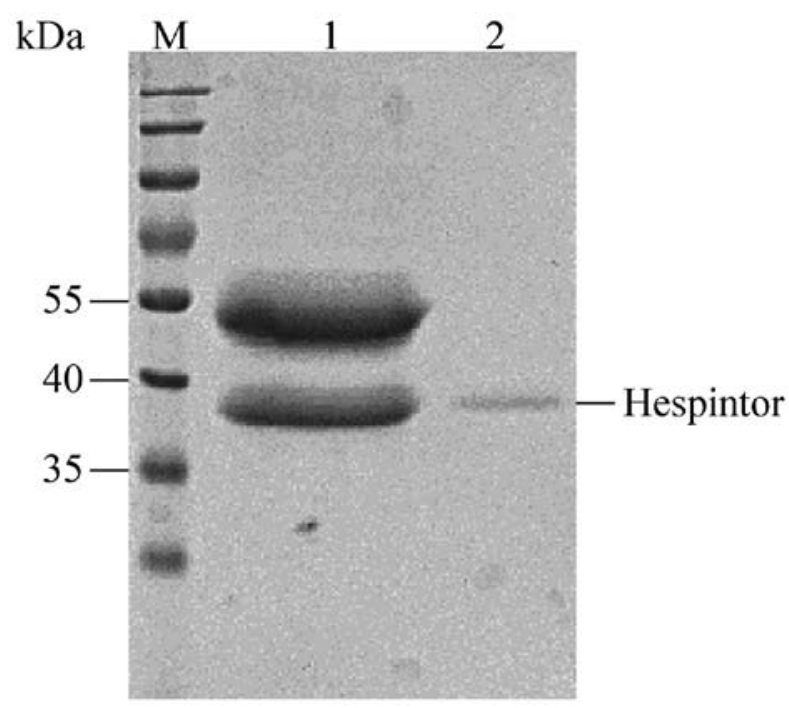

Figure 8. SDS-PAGE analysis of purified Hespintor recombinant protein from $\mathrm{Ni}^{2+}$ column and Q column. Lane M, PageRuler pre-stained protein ladder; lane 1, purified Hespintor recombinant protein from $\mathrm{Ni}^{2+}$ column; lane 2, purified Hespintor recombinant protein from Q column.

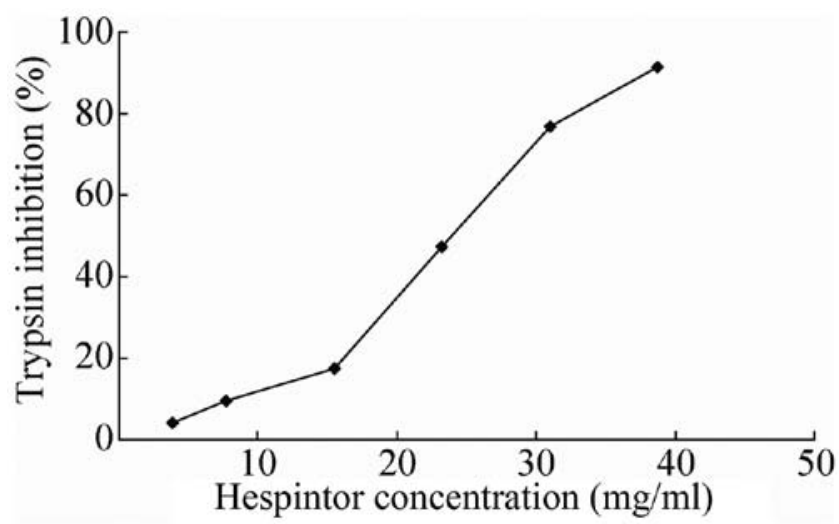

Figure 9. Inhibitory activity of purified Hespintor recombinant protein on trypsin.

an inclusion body (Fig. 5), accounting for $25.83 \%$ of the total bacteria proteins. Western blot analysis further indicated that the recombinant protein specifically interacted with the His monoclonal antibody (Fig. 6).

Purification, renaturation and identification of the recombinant fusion, protein Hespintor-Kazal. The inclusion body solution was examined by histidine affinity chromatography. The recombinant fusion protein, Hespintor-Kazal, was renatured and eluted by columns. The eluted target protein showed a single absorption peak monitored by the protein elution curve (Fig. 7A). The SDS-PAGE results revealed that the proteins purified by the $\mathrm{Ni}^{2+}$ column mainly migrated in the form of 2 bands, and there were few impurity proteins. Therefore, the protein products purified by affinity chromatography were analyzed by anion exchange chromatography (Fig. 7B). Finally, the single specific band of the target protein was obtained by SDS-PAGE detection (Fig. 8). The concentration of the puri- 


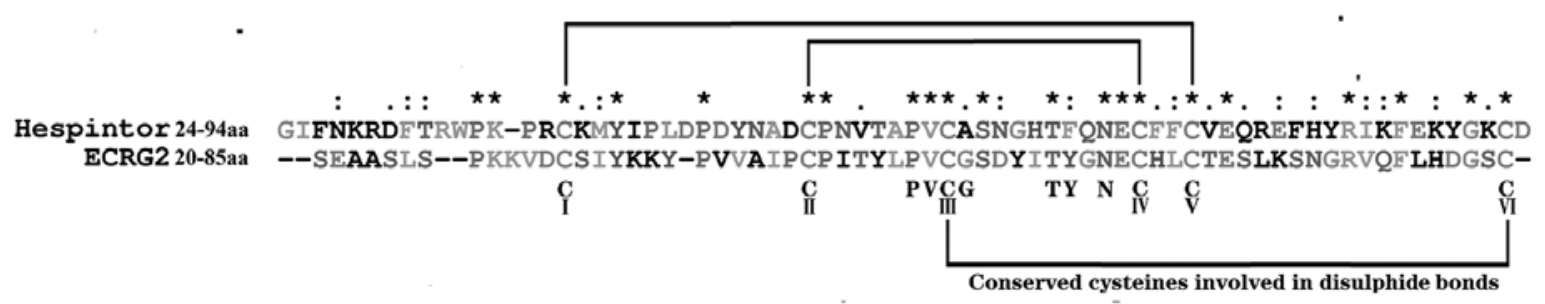

Figure 10. Alignment of the Kazal domain in the mature protein sequence of Hespintor and esophageal cancer-related gene 2 (ECRG2).

fied protein was $193.678 \mu \mathrm{g} / \mathrm{ml}$ measured by the Bradford method. That is, $0.77 \mathrm{mg}$ of the recombinant fusion protein, Hespintor-Kazal, was obtained from 1 litre of bacteria liquid following the induction of expression after the bacteria liquid was crushed by ultrasonic wave and purified by the two-step columns of $\mathrm{Ni}^{2+}$ and $\mathrm{Q}$.

Activity identification of the recombinant fusion protein, Hespintor-Kazal. Trypsin can hydrolyze BAPNA and produce colorless benzoyl-L-arginine and sandy p-nitroaniline, and the solution was light brown. If excessive trypsin inhibitors are added into the system, the hydrolytic activity of trypsin is inhibited, and the substrates cannot be hydrolyzed and paranitroanilinum cannot be produced. Thus, the solution is colorless. The results demonstrated that the trypsin inhibition rate of the recombinant fusion protein, Hespintor-Kazal, increased with the increase in protein concentrations. When the protein concentration was $38.74 \mathrm{mg} / \mathrm{ml}$, the trypsin inhibition rate reached $91.57 \%$. Thus, the inhibitory effects of the recombinant fusion protein, Hespintor-Kazal, on trypsin were high, and the inhibition curve showed a dose-dependent trend (Fig. 9).

\section{Discussion}

Previous studies have demonstrated that the ECM and BM degradation abilities of proteases produced by tumor cells are closely related to the invasive and metastasic ability of cells. The activity of proteases can be regulated at multiple levels (5-7). In cascade reactions, uPA plays a key role and is believed to be the rate limiting step for local tumor invasion and/or distant metastasis formation. Although the activity of proteases can be regulated at multiple levels, the most direct method involves the blocking of protease activity $(6,8)$. Therefore, controlling the uPA level or function may be an effective method for the treatment of tumors.

Serine protease inhibitor (serpin) is a regulatory factor that controls the activity of serine serine proteases. According to their sequence characteristics and three-dimensional structures, serpins are classified as 18 non-homologous protein families, of which the inhibitory effects of the Kazal-type serpin on uPA activity are the most direct and have the most prospects in clinical applications $(9,10)$. Kazal-type serpin is one of the most conservative families, with small molecule polypeptides that can sometimes inhibit tumor cell proliferation and invasion, and thus it has become a novel target for tumor therapy (11-15). Protein sequence analysis revealed that Hespintor possessed the basic serpin structure and was highly homologous to esophageal cancer-related gene 2 (ECRG2) (Fig. 10). The $\mathrm{C}$-terminal of the mature protein sequence of Hespintor and ECRG2 contains a typical CI-X(1-7)-CII-X(5)-PVCIII-X(5)$\mathrm{T}-\mathrm{X}(2)-\mathrm{N}-\mathrm{X}-\mathrm{CIV}-\mathrm{X}(2-6)-\mathrm{CV}-\mathrm{X}(9-17)-\mathrm{CVI}$ conserved region, coding a Kazal type serine protease inhibitor domain. As ECRG2 inhibits the proliferation, invasion and metastasis of tumor cells, it is possible that Hespintor also has the same ability against tumors $(8,16-18)$.

In this study, Hespintor was cloned to the prokaryotic expression vector, pET-40b(+), and the expression of the fusion and tagged protein Hespintor-Kazal was induced by IPTG. The PET-40b(+) prokaryotic expression vector had two notable features. The first was that it contained the $\mathrm{T} 7$ promoter, recognized by the T7 RNA polymerase provided by the host cells. The transcription efficiency of the T7 RNA polymerase was 5-fold higher than that of the Escherichia coli RNA polymerase. The T7 RNA polymerase can highly and efficiently transcript mRNA and many fusion proteins were expressed. The second feature was that the PET-40b(+) prokaryotic expression vector carried Dsbc-Tag, His Tag and S Tag. The induced expression of the $35 \mathrm{kDa}$ tag protein had little effect on the structure and biological activity of the targeted proteins. In particular, the His Tag before and after the target proteins provided the best affinity sites for further purifications of proteins. In addition, enzyme digestion sites of thrombin and enterokinase existed between the tag and target proteins, which were convenient for the removal of tagged proteins after purification of the target proteins (19). Induction conditions are an important factor affecting the expression of exogenous proteins. Furthermore, the induction temperature, induction time and IPTG concentration are essential for the production of the protein, Hespintor. Since interactions occur among these 3 factors, orthogonal experiments should be adopted. The results revealed that changes in induction conditions had no obvious effect on the expression of the recombinant proteins. The present study found that the solubility of the recombinant proteins was not enhanced and the expression of the recombinant proteins did not improve even when the concentration of IPTG decreased to $0.1 \mathrm{mmol} / 1$ and a low induction temperature of $16^{\circ} \mathrm{C}$ was used. As there were slight differences in the single factor experiment results, only the best single factor condition was used for the induction and expression of recombinant proteins.

In the protein purification and refolding process, the $\mathrm{Ni}^{2+}$ column was used for affinity chromatography, and the obtained elution curve was a single peak. Subsequently, SDS-PAGE analysis showed 2 protein bands; one had a molecular weight of $42 \mathrm{kDa}$, which was the recombinant protein, and the other had a molecular weight of $50 \mathrm{kDa}$, which was unknown and did not 
appear in the electrophoresis detection before purification. The analysis results illustrated no multiple associations between the molecular weight of the impurity protein and the molecular weight of the recombinant protein, which was not a recombinant dimer or multimer of the proteins. It is possible that the refolding and aggregation speed was sometimes too fast when the recombinant protein refolded, leading to the random aggregation formation of certain protein species by the 2 disulfide bonds. The SDS-PAGE results demonstrated that some recombinant proteins were still present in the loaded liquid flow of the $\mathrm{Ni}^{2+}$ column, indicating that the affinity of the $\mathrm{Ni}^{2+}$ column on the recombinant His tag protein did not reach saturation, or that the recombinant protein structure itself limited the affinity of the $\mathrm{Ni}^{2+}$ column on the His tag $(20,21)$. Based on the above analysis, $500 \mathrm{mmol} / 1$ of imidazole was selected to directly elute the $\mathrm{Ni}^{2+}$ column instead of gradient elution to facilitate subsequent protein purification. The predicted isoelectric point $(\mathrm{pI})$ of the recombinant protein was 7.12 and the $\mathrm{pH}$ of the solution buffer was 8.0, thus the Q column was chosen to conduct anion exchange chromatography. Finally, the single band recombinant product protein was obtained.

In this study, the prokaryotic expression system, HespintorKazal, was successfully constructed, and the purified recombinant fusion protein was obtained, which demonstrated the expected biological activity. The purification and refolding process of the recombinant fusion protein, Hespintor-Kazal, as well as the in vivo and in vitro anti-tumor activity of the protein required further investigation in future studies.

\section{Acknowledgements}

The authors thank the technical staff of the Department of Biotechnology, Beijing Centre for Physical and Chemical Analysis, Beijing, P.R. China, for providing excellent technical assistance.

\section{References}

1. Rao JS: Molecular mechanisms of glioma invasiveness: the role of proteases. Nature reviews. Cancer 3: 489-501, 2003.

2. Huang G, Li M, Cui Y, Li Y, Guo L, Jiang W and Lu SH: ECRG2 inhibits cancer cell migration, invasion and metastasis through the down-regulation of uPA/plasmin activity. Carcinogenesis 28 : 2274-2281, 2007.

3. Bekes EM,Kupriyanova TA,Zajac E, Botkjaer KA, Andreasen PA and Quigley JP: Activation of pro-uPA is critical for initial escape from the primary tumor and hematogenous dissemination of human carcinoma cells. Neoplasia 13: 806-821, 2011.

4. Legrand C, Tournier JM, Bentzmann S de, Huet E, Monteau M and Birembaut P: uPA/plasmin system-mediated MMP-9 activation is implicated in bronchial epithelial cell migration. Exp Cell Res 264: 326-336, 2001.
5. Aureli L, Gioia M, Cerbara I, Monaco S, Fasciglione GF, Marini S, Ascenzi P, Topai A and Coletta M: Structural bases for substrate and inhibitor recognition by matrix metalloproteinases. Curr Med Chem 15: 2192-2222, 2008.

6. Fisher JF and Mobashery S: Mechanism-based profiling of MMPs. Methods Mol Biol 622: 471-487, 2010.

7. Steverding D, Caffrey CR and Sajid M: Cysteine proteinase inhibitors as therapy for parasitic diseases: advances in inhibitor design. Mini Rev Med Chem 6: 1025-1032, 2006.

8. Cheng X, Lu SH and Cui Y: ECRG2 regulates ECM degradation and uPAR/FPRL1 pathway contributing cell invasion/migration. Cancer Lett 290: 87-95, 2010.

9. Olson ST and Gettins PG: Regulation of proteases by protein inhibitors of the serpin superfamily. Prog Mol Biol Transl Sci 99: 185-240, 2011.

10. Potempa J, Korzus E and Travis J: The serpin superfamily of proteinase inhibitors: structure, function, and regulation. J Biol Chem 269: 15957-15960, 1994.

11. Pantoja-Uceda D, Arolas JL, Aviles FX, Santoro J, Ventura S and Sommerhoff CP: Deciphering the structural basis that guides the oxidative folding of leech-derived tryptase inhibitor. J Biol Chem 284: 35612-35620, 2009

12. Soon WW, Miller LD, Black MA, Dalmasso C, Chan XB Pang B, Ong CW, Salto-Tellez M, Desai KV and Liu ET: Combined genomic and phenotype screening reveals secretory factor SPINK1 as an invasion and survival factor associated with patient prognosis in breast cancer. EMBO Mol Med 3: 451-464, 2011.

13. Shigemasa K, Gu L, Tanimoto H, O'Brien TJ and Ohama K: Human kallikrein gene 11 (KLK11) mRNA overexpression is associated with poor prognosis in patients with epithelial ovarian cancer. Clin Cancer Res 10: 2766-2770, 2004.

14. Horiguchi A, Sumitomo M, Asakuma J, Asano T, Asano T and Hayakawa M: 3-hydroxy-3-methylglutaryl-coenzyme a reductase inhibitor, fluvastatin, as a novel agent for prophylaxis of renal cancer metastasis. Clin Cancer Res 10: 8648-8655, 2004.

15. Cao D, Zhang Q, Wu LS, Salaria SN, Winter JW, Hruban RH, Goggins MS, Abbruzzese JL, Maitra A and Ho L: Prognostic significance of maspin in pancreatic ductal adenocarcinoma: tissue microarray analysis of 223 surgically resected cases. Mod Pathol 20: 570-578, 2007.

16. Song H, Song C, Wang H, Li C, Yang F, Lu SH, Lin C, Zhan Q, Wang $X$ and Qian H: Suppression of hepatocarcinoma model in vitro and in vivo by ECRG2 delivery using adenoviral vector. Cancer Gene Ther 19: 875-879, 2012.

17. Cheng X, Shen Z, Yin L, Lu SH and Cui Y: ECRG2 regulates cell migration/invasion through urokinase-type plasmin activator receptor (uPAR)/betal integrin pathway. J Biol Chem 284: 30897-30906, 2009.

18. Cui Y, Bi M, Su T, Liu H and Lu SH: Molecular cloning and characterization of a novel esophageal cancer related gene. Int J Oncol 37: 1521-1528, 2010.

19. Meng E, Cai TF, Li WY, Zhang H, Liu YB, Peng K, Liang S and Zhang DY: Functional expression of spider neurotoxic peptide huwentoxin-I in E. coli. PloS One 6: e21608, 2011.

20. Li J, Wu R, Chen H, Zhou Y, Li Y, Wang Y, Liu Y and Liu M: The cloning and characterization of the enolase2 gene of Gekko japonicus and its polyclonal antibody preparation. Int $\mathbf{J}$ Mol Sci 14: 8787-8800, 2013.

21. Jin Q, Yang LX, Jiao HM, Lu B, Wu YQ and Zhou YC: Purification, gene cloning and expression of an acidic phospholipase A2 from Agkistrodon shedaoensis Zhao. Acta Biochim Biophys Sin (Shanghai) 36: 27-32, 2004. 